University of Nebraska - Lincoln

DigitalCommons@University of Nebraska - Lincoln

Papers in the Earth and Atmospheric Sciences

Earth and Atmospheric Sciences, Department

$4-12-2013$

\title{
A hydro-climatological lake classification model and its evaluation using global data
}

Brandi Bracht-Flyr

University of Nebraska-Lincoln, brachtflyr@huskers.unl.edu

Erkan Istanbulluoglu

University of Washington, Seattle, erkani@u.washington.edu

Sherilyn C. Fritz

University of Nebraska-Lincoln, sfritz2@unl.edu

Follow this and additional works at: https://digitalcommons.unl.edu/geosciencefacpub

Bracht-Flyr, Brandi; Istanbulluoglu, Erkan; and Fritz, Sherilyn C., "A hydro-climatological lake classification model and its evaluation using global data" (2013). Papers in the Earth and Atmospheric Sciences. 377. https://digitalcommons.unl.edu/geosciencefacpub/377

This Article is brought to you for free and open access by the Earth and Atmospheric Sciences, Department of at DigitalCommons@University of Nebraska - Lincoln. It has been accepted for inclusion in Papers in the Earth and Atmospheric Sciences by an authorized administrator of DigitalCommons@University of Nebraska - Lincoln. 


\title{
A hydro-climatological lake classification model and its evaluation using global data
}

\author{
Brandi Bracht-Flyr, ${ }^{1}$ Erkan Istanbulluoglu, ${ }^{2}$ and Sheri Fritz ${ }^{1}$ \\ 1. Department of Earth and Atmospheric Sciences, University of Nebraska-Lincoln, 214 Bessey Hall, Lincoln, NE 68588, USA \\ 2. Department of Civil and Environmental Engineering, University of Washington, 201 More Hall, Seattle, WA 98195, USA \\ Corresponding author - B. Bracht-Flyr, tel 402 471-1697, email brachtflyr@huskers.unl.edu
}

\begin{abstract}
For many of the world's lakes, particularly those in remote regions, an assessment of the basin's sensitivity to climate change is limited by the availability of appropriate hydrologic data. A regional steady-state lake water balance model was developed that uses simple, yet easily estimated or obtained, data to generate an aridity index (potential evapotranspiration to precipitation ratio) to predict changes in lake basin area to lake surface area ratio, a non-dimensional lake-basin property that can be easily obtained from digital maps. In the model, lake water balance components include precipitation, lake evaporation, and runoff into the lake. Both basin runoff and evaporation are incorporated in the analytical model using an empirical equation (based on the Budyko hypothesis) that utilizes the aridity index and a calibration parameter to account for vegetative influence. Observed records of lake to basin area ratio, as a function of their evapotranspiration to precipitation ratio, for a range of climates and land cover conditions, were plotted and compared to a family of calculated steadystate curves. Dividing the domain of calculated curves into regions of permanent, land-cover change sensitive, and ephemeral lakes allows for comparison of model predicted lake classification with lake sediment records. The impact of land cover and climate change on lake persistence is also discussed. The model is most applicable for closed basin lakes in sub-humid, semi-arid, and arid environments. The model can be used: (1) as a diagnostic tool to analyze lake response to climate change; (2) to assess environmental and anthropogenic factors leading to transient lake response; and (3) as a paleoclimatic research tool, to identify lakes that can potentially provide high-resolution paleorecords of water balance.
\end{abstract}

Keywords: Lake, Water balance, Paleorecord

\section{Introduction}

Understanding how climate change affects lakes is essential for managing water resources and the associated ecosystem services, as well as for interpreting lacustrine records of past climate variability. An increasing number of studies suggest that time series of data that span several hundred to several thousand years are necessary to understand the full range of natural climatic and hydrologic variability (Alley et al., 2003, Cook et al., 2007, Stine, 1994 and Woodhouse et al., 2009). Among the tools that expand the temporal framework to times prior to those recorded in the instrumental climate record are lake sediment cores, which can be used to reconstruct past hydrologic variation and how that variation affected ecosystem processes (Shapley et al., 2002, Stone and Fritz, 2006 and Whitlock et al., 2012). Multiple factors affect the sensitivity of a lake basin to different aspects of climate and the extent to which climate change is recorded in lake sediments (Bracht et al., 2008, Gasse et al., 1987 and Stone and Fritz, 2004). These include position within the landscape, size, bathymetry, groundwater connectivity, anthropogenic influences, as well as the magnitude, nature, and season- ality of climate variation. Thus, climate patterns are more clearly inferred from certain types of lakes and in certain settings, but may be confusing or ambiguous in others (Fritz, 2008 and George and Hurley, 2003).

Lake models can be used to provide insight into how lakes respond to specific aspects of climate change through quantification of the hydrologic balance (Hostetler et al., 1994, Tate et al., 2004 and Zlotnik et al., 2009). Most prior modeling studies of lacustrine hydrology considered an individual lake or a small suite of lakes and their responses to changes in temperature, solar radiation, precipitation, or CO2 (Hostetler et al., 2000, Vassiljev, 1998 and Vassiljev et al., 1995). However, such focused studies do not provide a large-scale picture of lake hydrologic response in relation to geographic location and regional climate conditions (Bennett et al., 2007, Sass et al., 2008, Vassiljev et al., 1995 and Webster et al., 2000). Other lake modeling studies have used general circulation models to reconstruct regional water balance at times in the past and compared model predictions with paleodata, including lake-level reconstructions, in order to better understand the mechanisms of regional climate change in the past (Kohfield and Harrison, 2000 and Street-Perrott and Harrison, 1985). 
We developed a steady-state, basin-lake water balance model that predicts basin area to lake area ratio ( $\left.\mathrm{A}^{\prime}\right)$ as a function of mean annual climate, quantified by an aridity index, $\Phi$ (mean annual potential evapotranspiration to precipitation ratio), expressed in a family of curves on an $\mathrm{A}^{\prime}-\Phi$ domain. Vegetation influences the basin runoff into a lake; therefore, we include the effects of basin vegetation within the model through an empirical calibration parameter. Based upon the vegetation-specific steady-state thresholds, we identify several lake classification regions defined on the $\mathrm{A}^{\prime}-\Phi$ domain: permanent (those that do not desiccate), land cover (LC) sensitive, and ephemeral (desiccates frequently). The model can be used to evaluate the extent to which lake level in a given basin (implicit in the $\mathrm{A}^{\prime}$ value of a lake) responds to climate change relative to other non-climatic influences. Our approach is similar to that of Bowler (1981), in which a lake stability classification scheme, based upon water-balance components, was developed and implemented for Australian lakes. Bowler (1981) did not calculate runoff and evaporation explicitly but assigned values to these model parameters. However, in this paper we calculate runoff and evapotranspiration explicitly, using an aridity index based method that allows for climatic classification and incorporates vegetative influences.

This conceptual climatic lake model is designed to be simplistic, while requiring a minimum number of input parameters. The conceptual model relies on several base assumptions: (1) steady-state water balance, (2) uniform basin climate (including over lake and basin), (3) closed-basin lake system (including groundwater fluxes), (4) no anthropogenic influences, and (5) appropriate time-scale (some extremely large lakes may have long response times due to their storage capacities). Our methodology provides a means to identify other lake-basin hydrologic controls that influence lake-level variation, which could be critical to examine lake hydrology under limited hydrologic information. For example, the model can be used whether or not the lake has significant surface inflow or outflow, or whether groundwater fluxes are a substantial portion of the water budget. Also, the proposed model can be used to get insights on a lakes sensitivity to changes in the mean annual climate, and its potential to preserve a complete sediment record of climate history.

In this paper first we describe the conceptual model. By using lake plotting position in a two-dimension space, we then evaluate lake sensitivity, which we define as the change in $\Phi$ or $\mathrm{A}^{\prime}$ required to change a lakes plotting position to a different classification category. We evaluate our classification model against observations from 150 lakes, spanning six continents. We identify lakes whose dominant controls on lake level are climate and lake area/surface area interactions, or if other parameters are important in affecting lake-level variation. This model may be useful in evaluating sites for specific hydrologic or paleoclimate questions, regional controls on lake level, or lake response to land-use change.

\section{Methods}

\subsection{Analytical model}

The simplistic conceptual model is presented below. Model limitations are discussed as we present the model, as well as in the discussion section of the paper. The annual water balance of a closed lake basin can be written as (e.g. Street-Perrott and Harrison, 1985):

$$
\Delta V=A_{l}\left(P_{l}-E_{l}\right)+R_{b} A_{b}+\left(G_{i}-G_{o}\right)
$$

where $\Delta V$ is the net annual change in the lake volume, $A_{l}$ is the lake surface area, $P_{l}$ is precipitation over the lake, $E_{l}$ is evaporation from the lake, $R_{b}$ is the basin runoff generated uniformly over the contributing area of the basin, $A_{b}$ is the contributing ba$\sin$ area, and $G_{i^{\prime}} G_{o}$ are the groundwater fluxes in and out of the lake, respectively. Assuming that an equilibrium condition is attained between the fluxes of water into and out of the lake volume and that a net groundwater transfer is negligible, a closedbasin, steady-state lake water balance can be expressed as:

$$
0=A_{l}\left(P_{l}-E_{l}\right)+R_{b} A_{b}
$$

A climatological classification of lake water balance should use some directly measurable lake and basin attributes, and an index that describes the regional climate, such that these properties can be plotted in a two-dimensional space, along with the predictions of the conceptual model. Earlier works on water-balance lake classification used lake to basin area ratio to further simplify Equation (3) into a non-dimensional form (Bowler, 1981; Street-Perrott and Harrison, 1985). In this model, instead of using a lake to basin area ratio, we prefer to use a basin area to lake area ratio. Thus, both sides of Equation (2) are divided by $A_{l}$ to obtain this ratio. Using $A^{\prime}=A_{b} / A_{l}$ as an area index, we obtain:

$$
0=P_{l}-E_{l}+R_{b} A^{\prime}
$$

In our simplified steady-state model we propose to estimate $R_{b}$ and $E_{l}$ from the Budyko hypothesis (Budyko, 1974). Budyko (1974) postulated that the mean annual actual evapotranspiration $\left(E T_{a}\right)$ of a basin asymptotically approaches a very small value as climate becomes wetter, and approaches the mean annual precipitation over the basin $(P)$ as climate becomes dry. When climate aridity is represented by $\Phi=E T_{p} / P$, where $E T_{p}$ is the maximum or potential mean annual evapotranspiration, the hypothesis postulated by Budyko (1974) leads to the following limit conditions for $E T_{a} / P$ :

$$
\frac{E T_{a}}{P}= \begin{cases}F(\Phi) \rightarrow 0, & \Phi \rightarrow 0 \\ F(\Phi) \rightarrow 1, & \Phi \rightarrow \infty\end{cases}
$$

where $F(\Phi)$ is an asymptotic function that could take various forms. The Budyko hypothesis has been widely used as a conceptual framework for examining basin water balance in a range of climates and environmental conditions, and for developing and validating regional hydrologic models ( Milly and Dunne, 1994; Choudhury, 1999; Koster and Suarez, 1999; Atkinson et al., 2002; Farmer et al., 2003; Porporato et al., 2004; Zhang et al., 2001, 2004, 2008). The simplistic nature of this hypothesis provides an opportunity to relate the steady-state lake water balance model to climate.

For $F(\Phi)$ we use the model proposed by Zhang et al. (2001):

$$
F(\Phi)=\frac{1+w \Phi}{1+w \Phi+\Phi^{-1}}
$$

where $w$ is an empirical parameter used to represent land cover and soil type. Assuming that $P$ is in balance with $R_{b}$ and $E T_{a}$ on a mean annual basis and that inter-basin groundwater flow is negligible, basin water balance normalized with respect to precipitation becomes:

$$
\frac{R_{b}}{P}+F(\Phi)=1
$$

Solving for $R_{b}$ gives:

$$
R_{b}=P(1-F(\Phi))
$$

In this simple model we propose to write Equation (3) as a function of three variables that can be directly estimated in a region: $P, \Phi$, and $A^{\prime}$. To limit the model to these variables, we made the following assumptions. First, using a single $P$, we assume that both the lake and the basin receive the same amount of mean annual precipitation $\left(P_{l}=P\right)$. Second, we assume that the mean annual basin $E T_{p}$ and lake evaporation $E_{l}$ are identical. This neglects the role of heat storage in lakes, which is more 
critical for deep lakes. The Food and Agricultural Organization (FAO), compares $E_{l}$ with the potential rate of evapotranspiration for a reference grass crop $\left(E T_{R}\right)$ over a year through the use of crop coefficients (Allen et al., 1998). The report suggests that in shallow waters $(\leq 2 \mathrm{~m}) E_{l}$ can be as much as 5\% higher than $E T_{R}$. For deeper waters where significant temperature changes in the lake profile could occur, $E_{l}$ was reported $35 \%$ lower until mid-season, and up to $25 \%$ higher than $E T_{R}$ after the middle of the growing season (Allen et al., 1998). However considering that over the mean annual time scales, the net change in the heat storage in a lake could be practically negligible, we argue that our assumption can be acceptable for a simplistic approximation of lake water balance applicable at the global scale. Using the aridity index, we can write $E_{1}=P \Phi$. Now substituting the expressions obtained for $R_{b}$ and $E_{l}$ into Equation (3), the steady-state lake-basin water balance reduces to:

$$
0=P(1-\Phi)+P(1-F(\Phi)) A^{\prime}
$$

This model can be illustrated in Figure 1, where both lake and basin area are represented by boxes, governed by water balance, with basin runoff entering the lake area. Note that in the equations above, we showed how $E T_{a}$ and $R_{b}$ can be approximated from the Budyko hypothesis, and $E_{l}$ from the aridity index.

The basin to lake area ratio $\left(A^{\prime}\right)$ required to maintain a steady-state balance of fluxes into and out of the lake can be calculated as a function of the aridity index by solving (8) for $A$ ' yielding:

$$
\mathrm{A}^{\prime}= \begin{cases}\frac{\Phi-1}{1-F(\Phi)} & \Phi \geq 1 \\ 0 & \Phi<1\end{cases}
$$

The behavior of this equation is illustrated on the $A^{\prime}-\Phi$ domain for different values of $w$, representing different land use conditions (Figure 2). The energy line (vertical dashed line) separates the domain into energy and water limited climates, and the ranges of different climates classified with respect to $\Phi$ are indicated on the $\mathrm{x}$-axis, according to Barrow (2006). Note that in Equation (8), $A^{\prime}>0$, if $\Phi>1$. When $\Phi<1$, the climate is energy limited and $E T_{p}$ falls below $P$ (Figure 2a). As a result, the model does not require $A^{\prime}$ in such humid regions where regional topography allows for closed depressions to store water. Thus, lakes in energy-limited regions, under a stationary climate, would be permanent, and their formation would solely be controlled by topography. In the water-limited portion of the $A^{\prime}-\Phi$ domain, $A^{\prime}$ increases nonlinearly as climate becomes arid due to increasingly larger basin areas to compensate the growing evaporative demand.

To illustrate the role of land cover (LC) in the $A^{\prime}-\Phi$ relation, we plot Equation (9) in Figure 2a for two typical values of $w$ representing grass $(w=0.5)$ and forest $(w=2.0)$ (Zhang et al., 2001), and a low value of $w=0.1$ to represent sandy soils and sparse vegetation (Wang et al., 2009). Conceptually we consider the region bound by the forest and sparse vegetation lines for a

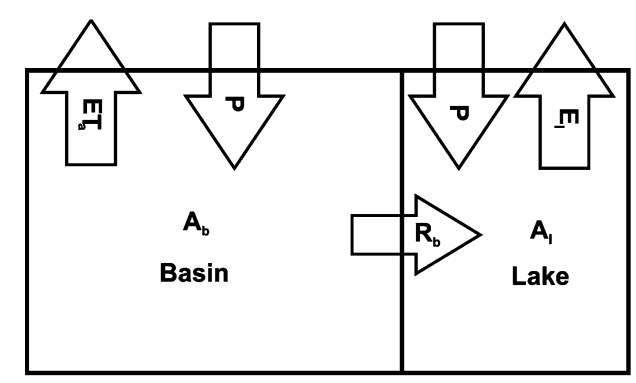

Figure 1. This schematic simply illustrates the main conceptual model components. It also shows the relationship between the basin and lake components.
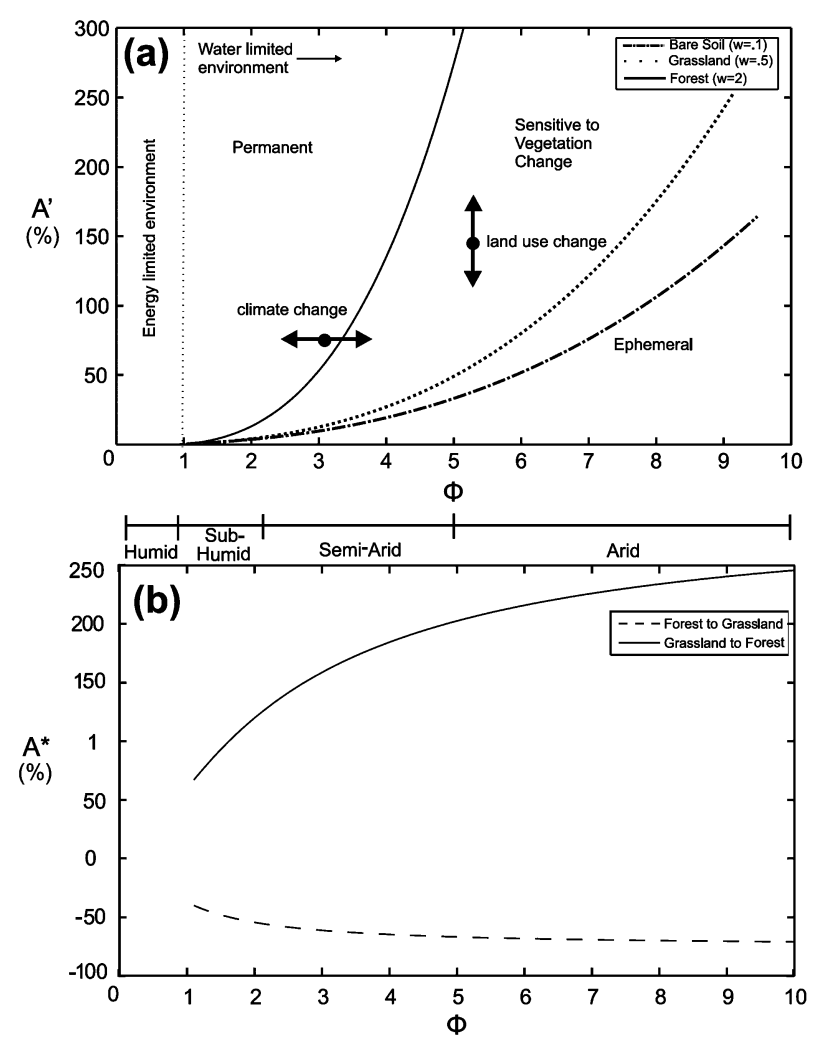

Figure 2. (a) $A^{\prime}-\Phi$ relations for three typical values of $w$ representing different land cover impacts, based on Zhang et al. (2001, 2004). The domain is separated into three different lake classification regions based on climate. The vertical dashed line separates the energy and water-limited environments. (b) Model sensitivity to land cover change, illustrated by plotting $A^{\star}$ (change in $A^{\prime}$ as a result of land cover change).

given $\Phi$ as a range of $A^{\prime}$ required to maintain lakes in a given climate. This threshold envelope between the forest and sparse vegetation increases as the climate becomes drier. This underscores the critical role of basin LC on lakes in arid climates. Conversely, in the sub-humid and energy-limited climates, the envelope between forest and sparse vegetation rapidly shrinks.

Lakes that fall above the forest threshold line can be considered permanent and insensitive to LC change as they have larger basin areas than required by the model. Lakes that fall below the lower threshold line can be considered ephemeral, as they have smaller basin areas than required by the model for sparse vegetation (LC). Ephemeral lakes would only form during the wet season or during wetter climate anomalies. We classify the lakes that fall between the upper and lower LC lines (threshold envelope) as LC sensitive lakes. In this region, lakes can be permanent, ephemeral, or conditioned on their LC type. For a given $\Phi$, a lake with a forested basin that plots below the $w=2.0$ threshold line would tend to show ephemeral behavior. We can further interpret the model results when individual lake data are calibrated with a $w$-value or a smaller range of $w$-values from basin runoff observations. In this case we expect that the smaller the observed $A^{\prime}$ of a lake compared to that calculated from Equation (9), the more frequently the lake will desiccate (or experience water losses) as a result of climate fluctuations. Conversely, with larger observed $A^{\prime}$ than required, the lake would be less susceptible to $\mathrm{LC}$ and climate change disturbances.

The conceptual model can also examine the impact of LC change on lake size. Figure $2 \mathrm{~b}$ illustrates the impact of LC change on basin to lake area ratio $\left(A^{\prime}\right)$ by plotting the percent change in $A^{\prime}$ as a result of LC change, calculated as: 
$A^{\star}=\frac{A_{\text {grassland }}^{\prime}-A_{\text {forest }}^{\prime}}{A_{\text {forest }}^{\prime}} * 100$ or $A^{\star}=\frac{A_{\text {forest }}^{\prime}-A_{\text {grassland }}^{\prime}}{A_{\text {grassland }}^{\prime}} * 100$

The two curves represent land-use-change impacts from forest to grassland conversion and vice versa on $A^{\prime}$ (first equation is forest to grassland). Forested basin $E T_{a}$ is larger than grassland $E T_{a}$. Under the same climate, a forested basin will need a larger $A^{\prime}$ (to maintain long-term steady-state water levels) than a grassland basin as it produces less runoff. In the case of grassland to forest conversion, a greater $A^{\prime}$ will be needed to maintain a lake water balance (positive $A^{\star}$ ) (Figure 2b). Since increases in basin size are unlikely, the implication of this would be reduction of lake size or desiccation of the lake. When land cover changes from forest to grassland under a constant $\Phi$, a lake would increase its size, leading to a reduction in $A^{\prime}$ (negative $A^{\star}$ ) (Figure $2 \mathrm{~b}$ ). Interestingly, the conceptual model predicts that land-use change would have different impacts on $A^{\prime}$ depending on climate. A more dramatic impact of land cover change is predicted as climate gets drier, especially in the case of forest to grassland conversion. For example, for an aridity index of 4 (semiarid climate), forest to grassland conversion gives a $\sim 65 \%$ increase in $A^{\prime}$ as the lake surface would grow and the basin area will remain relatively constant. Grassland-forest conversion would lead to more than a $180 \%$ decrease in $A^{\prime}$, and the difference continues as climate becomes more arid.

\subsection{Data}

We use the model as a diagnostic tool to evaluate, in relation to vegetative conditions, the observed $A^{\prime}-\Phi$ values of lakes, along with their records of desiccation frequencies globally to interpret certain lakes' sensitivity to climatic fluctuations. Lakes, over 150 globally, included in this study vary in location, surface area, volume, climate, and anthropogenic influence (Figure 3).

Data for lake surface area, watershed area, potential evapotranspiration, and precipitation come from a variety of sources and methods, including publications, GIS measurements of basin and lake area, and data from the International Water Management Institute (IWMI, http://www.iwmi.cgiar.org), the Northern Temperate Lakes Long Term Ecological Research (LTER, http://www.lter.limnology.wisc.edu), Experimental Lakes Area (ELA, http://www.experimentallakesarea. ca), World Lake Database (WLD, http://www.ilec.or.jp), the
Table 1. Lake data sources, see text for definition of acronyms.

\begin{tabular}{ll}
\hline Continent & Data source \\
\hline Africa & $\begin{array}{l}\text { Ayenew, 2003, Bergonzini, 2004 and Hamblin } \\
\text { et al., 2004 } \\
\text { Kutzbach, 1980, Nicholson and Yin, 2002 and } \\
\text { Song et al., 2002 } \\
\text { Morrill, 2004 and Qin and Huang, 1998, } \\
\text { WLD, IWMI }\end{array}$ \\
Asia & $\begin{array}{l}\text { Bowler (1981), IWMI, WLD } \\
\text { Gustralia }\end{array}$ \\
Europe & $\begin{array}{l}\text { Vassiljev et al. (1995), IWMI, WLD } \\
\text { North America }\end{array}$ \\
& $\begin{array}{l}\text { Allen, 2005 and Hostetler and Giorgi, 1995, } \\
\text { NOAA, LTER, ELA, USGS NED files }\end{array}$ \\
South America & $\begin{array}{l}\text { Blodgett et al., 1997 and Hastenrath, 1985, } \\
\text { Kessler (1983), WLD }\end{array}$ \\
\hline
\end{tabular}

National Oceanographic and Atmospheric Administration (NOAA, http://www.ncdc.noaa.gov), and United States Geological Survey NED files (http://www.seamless.usgs.gov) (Table 1). Limitations in data availability and type prevented using the same methodology to calculate each parameter. Lakes range in size from small ponds $\left(\leq 1 \mathrm{~km}^{2}\right)$ to large lakes, such as Baikal, Titicaca, and the African Rift Valley Lakes (greater than $10,000 \mathrm{~km}^{2}$ ). Drainage basin sizes also vary widely, but larger lakes generally have large drainage basins. Precipitation and potential evaporation values also vary, ranging from less than $20 \mathrm{~mm}$ /year to several thousand $\mathrm{mm} /$ year. The variable with the greatest range of uncertainty is potential evaporation, as it is estimated using a wide variety of methods and with different timescales. However, exact values are not vital, as the model mainly explores the relationships and relative changes among the variables considered.

Many of the lakes included in the analyses have paleorecords or lake-level records that give an indication of the frequency of lake desiccation, which we use to estimate the desiccation interval. Using potential lake desiccation intervals provides another tool for evaluating the model, as the position of the lake relative to the line describing steady-state conditions should indicate its propensity to stabilize in each of the three different states. The majority of desiccation intervals were obtained from the literature or paleorecords. Many permanent North American lakes that formed after the last gla-

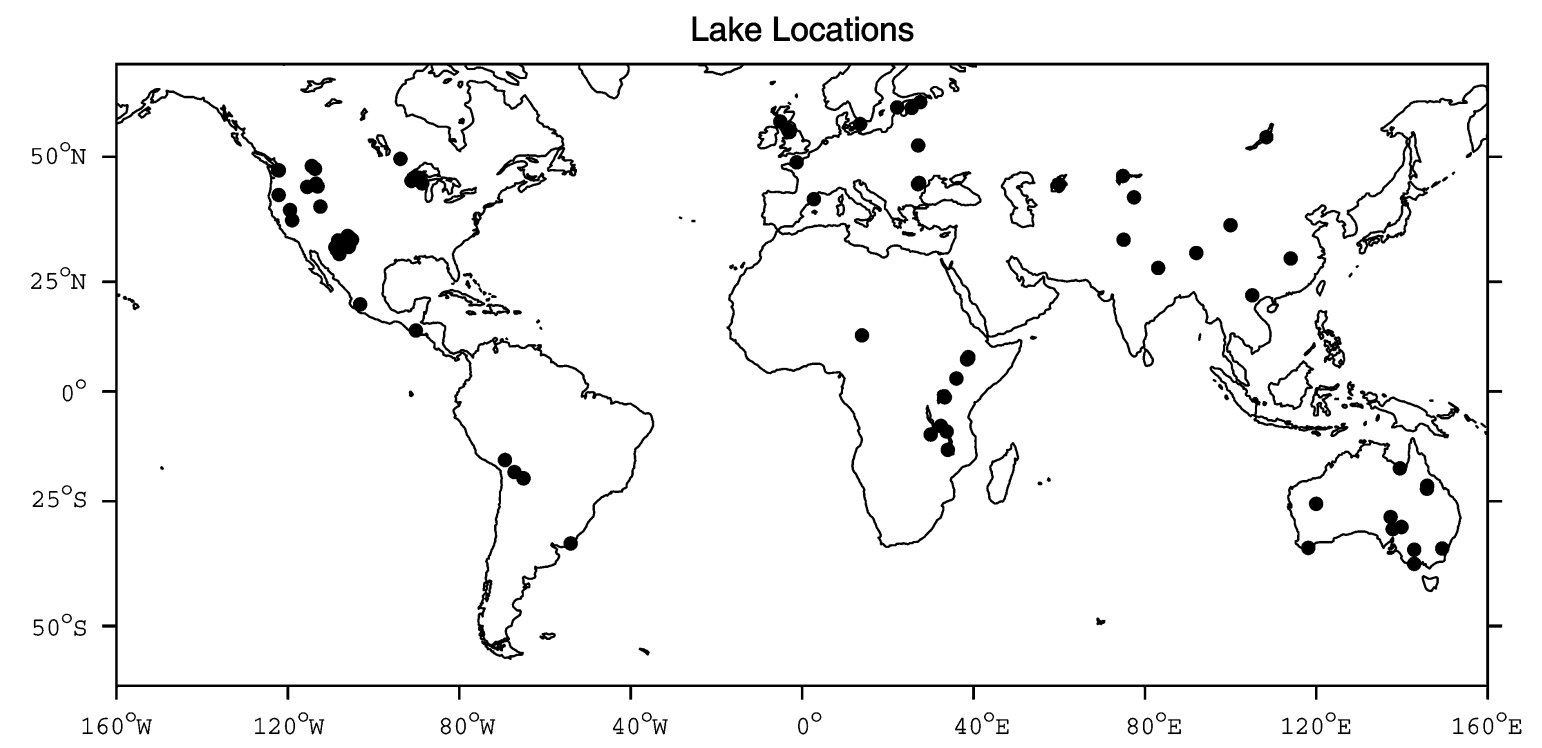

Figure 3. Locality map of the different lakes used in the $A^{\prime}-\Phi$ threshold model. Every continent was included in the study, with the exception of Antarctica. Some geographic regions are either over or under represented in the model, resulting from data availability. 
cial period were given a maximum desiccation interval of $10^{3}$. Other lakes that we could not obtain data for were given the value of $\geq 10^{3}$, as this is an intermediate value.

\section{Results}

Figure 4 plots $A^{\prime}-\Phi$ curves for different $w$-values and data for all considered lakes. The line marked, $w=2.5$, approximates highly vegetated forest conditions, or finer soil texture, while the line marked, $w=0.1$, approximates sparse to bare vegetation (Wang et al., 2009). We refer to these upper and lower end member lines as representing the threshold envelope for which lakes are most sensitive to land cover changes. The steady-state condition for an individual lake is heavily dependent upon the basin land cover, thus for individual lakes it may be important to consider a smaller, land cover specific, envelope rather than the entire range between spare vegetation and forest lines. However, since we discuss the plotting position of lakes in relation to their desiccation intervals, we have not further examined the land cover condition of each lake individually.

As climate gets drier, there is a clear decrease in the desiccation interval of the lakes. In Figure 4, the majority of the lakes that have long desiccation intervals (referred to as permanent lakes with respect to the current climate) tend to plot either in the $\Phi \leq 2$ region, or above the forest land cover line. Under the current climate, the permanent existence of these lakes is arguably not sensitive to their land cover conditions. A land cover change from forest to grass or vice versa would not lead to desiccation of the lakes classified as permanent.

Lakes that have short desiccation intervals (referred to as ephemeral lakes) tend to plot below the sparse vegetation curve. All of the lakes that show annual dry-ups plot in this portion of the lake classification domain. These lake data plotting positions are consistent with the lake classification regions defined by the conceptual model and the lake domains denoted in

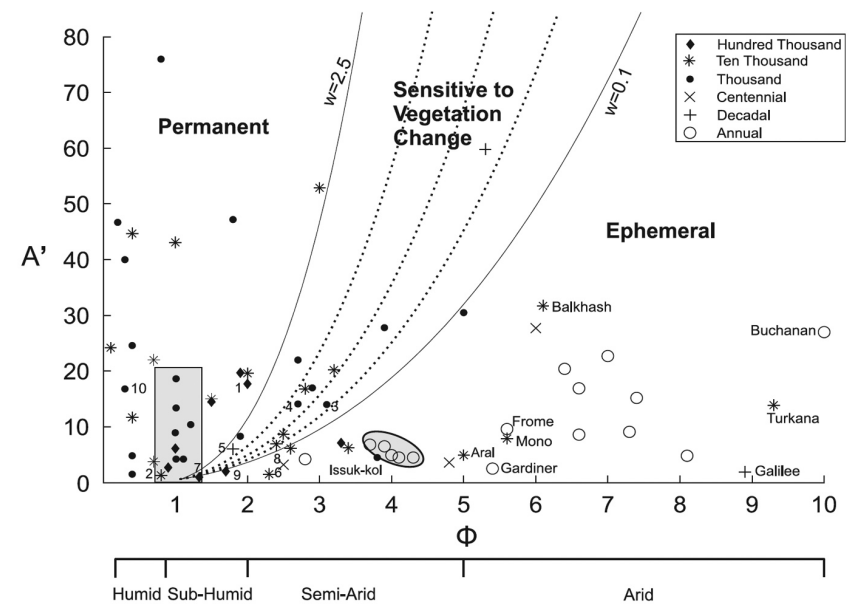

Figure 4. Lakes plotted on the $A^{\prime}-\Phi$ domain along with Equation (9) for a range of climates. The solid lines illustrate the effect of land cover for the two end-member vegetative possibilities, dense forest $(w=2.0)$ and sparse vegetation $(w=0.1)$. The dashed lines plot predicted $A^{\prime}$ as a function of $\Phi$ threshold values that result from different basin vegetative cover ( $w$-values). The gray box represents the range of $A^{\prime}-\Phi$ values for ELA and LTER lakes. The gray oval encompasses several southwestern US lakes. Labeled lakes are discussed in the paper. The number labels correspond to the following lakes: (1) Baikal, (2) Crater, (3) Crevice, (4) Foy, (5) George, (6) Keilambete, (7) Malawi, (8) Qinghai, (9) Titicaca, and (10) Windermere. The lakes are grouped by potential desiccation time. Lakes that desiccate frequently tend to plot far below the $A^{\prime}-\Phi$ thresholds, while lakes that never/rarely desiccate plot above of the threshold lines. Theoretically, lakes that plot within the envelope would be the most sensitive to land-use change.
Figure 2. We suggest that the farther away a lake plots from the limits of the land cover-sensitive envelope (higher or lower $A^{\prime}$ ), the more likely that other factors, such as local topography and hydrologic conditions, gain importance in lake dynamics. Many of these lake data plotting positions are consistent with the steady-state conditions of the conceptual model and the lake domains denoted in Figure 2a. However, some lakes deviate from these trends, which will be discussed below.

Prior knowledge of lake conditions in comparison to whether a lake plots in the permanent, land change sensitive, or ephemeral domain is useful in identifying possible controls on the hydrological conditions for a given lake. Based on the steady-state $A^{\prime}-\Phi$ curves and lake plotting positions, we interpret that certain lakes are more sensitive to climatic perturbations than others. For example, a lake that plots significantly below the land change sensitive envelope would require a larger increase in precipitation relative to evapotranspiration (i.e. decreases in $\Phi$ ) to prevent the lake from desiccating.

The Australian saltpan lakes (Buchanan, Gaililee, Gardiner, and Frome) and American southwestern lakes would require a substantial change in climate to become permanent (see Figure 4 caption to distinguish lake symbols). Conversely, a lake that plots only slightly below the sparse vegetation line would require only a small increase in precipitation to change from a basin that is losing water to a permanent lake. Thus, the saltpan lakes of Australia and ephemeral lakes of southwestern US have a higher probability of desiccating than many other lakes, as shown in Figure 4, resulting from both the high potential evapotranspiration and lack of a sufficiently large basin to compensate for evaporative losses. In the figure, lakes tend to group by desiccation interval (as indicated by the paleorecords), suggesting the large-scale importance of climate relative to local factors.

\section{Discussion}

Of the 171 lakes included within the study, lakes that plot within each category are: 125 permanent, 14 land cover change-sensitive, 28 ephemeral, and four that plot at the boundary of the sensitive to change envelope. In the $A^{\prime}-\Phi$ domain presented in Figure 4, in agreement with the conceptual model, the majority of the lakes with annual desiccation intervals plot within the ephemeral region of the domain, while a significant number of the lakes that exhibit infrequent desiccation plot within the permanent region. However, several data points do not plot within the expected model domain.

Some of the lakes that desiccate infrequently plot within the ephemeral domain, while some ephemeral lakes plot within the land change sensitive domain (Figure 2). According to the conceptual model, lakes that plot within the threshold envelope are mainly dominated by surface water inflows and may be considered to be in steady-state with climate. The lakes that do not fall within this envelope are not in steady-state conditions and may be gaining or losing volume. Alternatively, these lakes may be in steady state conditions, but their water balance is affected by other water fluxes, that are not accounted for in the conceptual model, such as groundwater fluxes or anthropogenic influences. In general, lakes that deviate from model predictions can be used to evaluate whether critical model assumptions are violated and thus whether hydrologic controls not included in the conceptual model are important in affecting lake-level dynamics. In the following paragraphs, we provide some examples.

Lake Turkana, which is one of the world's largest permanent and alkaline desert lakes, plots within the ephemeral lake region. It is likely that Lake Turkana violates the second assumption of uniform climate across the lake basin region. The main water source for Lake Turkana, the Omo River, flows 620 miles before reaching the lake, and originates in much wetter regions 
than Lake Turkana itself. Crater Lake, Oregon, USA and the LTER, Wisconsin, USA, lakes likely violate the third assumption of closed lake basin systems, as they likely have significant groundwater fluxes. These lakes plot within the energy-limited portion of the permanent lakes domain, do not have surface water outlets, and receive greater amounts of precipitation than necessary to maintain lake-levels. In both settings, losses to the regional groundwater systems are important components of the regional lake water balances (Redmond, 2007; Webster et al., 1996) and this hydrologic connectivity likely causes the lakes to fluctuate in level more than the model predicts. For example, Crater Lake loses more than $100 \mathrm{~cm} /$ year to seepage (Redmond, 2007). Similarly, Lake George, Australia, which plots within the land cover change-sensitive region, exhibits frequent, decadal, desiccation and also likely violates the third conceptual model assumption because its water balance is affected by groundwater seepage (Jacobson et al., 1991).

Lake Qinghai is an example of a lake that violates the fourth assumption, lack of anthropogenic impacts. Lake Qinghai plots near the land cover change-sensitive domain, but decreased from $4980 \mathrm{~km}^{2}$ to $4304 \mathrm{~km}^{2}$ between 1908 and 1986 (Qin and Huang, 1998). The decrease in Lake Qinghai surface area may largely be attributed to significant loss of riverine inputs, because many tributary streams, such as the Buha River, are now dry as a result of anthropogenic water extractions ( $\mathrm{Li}$ et al., 2007). The plotting position of Lake Qinghai puts it in the boundary between the sensitive and ephemeral lake regions, illustrating the very sensitive nature of this lake to changes in climate and land use.

Issyk-kul, Lake Balkhash, Mono Lake, and the Aral Sea are within semi-arid to arid regions and plot within the ephemeral region of the domain. These large lakes are more stable than some geographically similar, smaller lakes. Violation of both the fourth and fifth assumptions, the lack of anthropogenic influence and the massive water storage capacities of these lakes may prevent or slow desiccation. While more stable than other smaller regional lakes, these lakes are currently shrinking as a result of climate change, in some cases compounded by anthropogenic use (Aizen et al., 2007; Gao et al., 2011; Micklin, 2007; Qin and Huang, 1998). (Note that paleolimnologic evidence suggests that the Aral Sea has desiccated in the past (Aizen et al., 2007)). We do not intend to minimize anthropogenic changes to these lakes, but rather emphasize the importance of managing water resources in basins that are likely to be sensitive to natural climate perturbations. Therefore, we suggest that the lakes that plot in the ephemeral region of the $A^{\prime}-\Phi$ domain are a prime focal point for sustainable management because severe declines or desiccation are likely.

The model can help to identify lakes that might produce highly resolved lake-level reconstructions that reflect climate driven fluctuations in the hydrologic budget. In the conceptual model explored in this paper, ideally, lakes that are sensitive to climate variation should plot near the threshold envelope, as these lakes require the smallest perturbations in potential evapotranspiration or precipitation to switch from one domain to another (e.g., land cover change sensitive to permanent). This can be further refined for individual lakes if enough is known about the land cover or vegetation of the ba$\sin$ to constrain the $w$-values. Comparison of the model to paleolake records shows that many "classic" sites used for lakelevel reconstructions plot near the land cover adjusted $A^{\prime}-\Phi$ threshold line. Lakes, such as Lake Titicaca and Lake Malawi (African Rift Valley), plot almost on the threshold line, suggesting that these lakes are quite sensitive to climate fluctuations. Both of these lakes have highly resolved records that show large fluctuations in lake depth ( Baker et al., 2001; Cohen et al., 2007; Fritz et al., 2007). Several other lakes that plot within or near the threshold envelope, including Lake Baikal, Lake Keilambete, and Foy Lake, also have highly resolved paleorecords that suggest these lakes are quite sensitive to variation in the hydrologic balance ( Bowler, 1981; Mackay, 2007; Stevens et al., 2006). Timescale is am important consideration in evaluating lake sensitivity to changes in hydrologic balance; lakes may not be particularly sensitive to yearly or decadal fluctuations in climate, but may provide high lake sensitivity on longer timescales (e.g. Shinneman et al., 2010).

The conceptual model also may be used to approximate the magnitude of climate change that produced lake-level patterns evident in paleorecords, particularly during lake inception and desiccation. The model approximates steady-state conditions for lake size and basin size, under non-transient climate. However, lakes often persist throughout a variety of climate regimes, which affect $\Phi$ and $A^{\prime}$. For example, the Great Salt Lake is a remnant of a large paleolake called Lake Bonneville, which occupied parts of the Great Basin region during pluvial periods in the past. It may be possible to estimate the aridity index during the Pleistocene inception of Lake Bonneville, (maximum surface area, 51,300 $\mathrm{km}^{2}$ ), although the region is currently a salt flat (Benson et al., 1992). The basin was not included in our plot, because many model parameters could not be measured, but it would be likely plot below any of the land cover-specific threshold lines. However, during lake inception, $\Phi$ would be considerably lower, which would produce incoming fluxes that were greater than outgoing fluxes, and thus lake formation. This change in $\Phi$ would move the lake position within the threshold envelope, and provide a semi-quantitative, estimation of climatic change. Pollen records from surrounding regions could be used to estimate $w$ at lake inception to more accurately predict paleo- $\Phi$ values.

\section{Conclusions}

In this paper a lake water balance equation that predicts the basin to lake surface area ratio $\left(A^{\prime}\right)$ for a given climate, characterized by an index of aridity ( $\Phi$, potential evaporation to precipitation ratio), and basin soil and land cover conditions is developed, which is most appropriate for closed basin lakes in non-humid climates. Based on the conceptual model a lake hydro-climatological classification idea is presented that stems from the work of Bowler (1981). Our classifications separate the $A^{\prime}-\Phi$ domain into ephemeral, permanent, and land cover change-sensitive lake regions. The model presented here is applied to multiple lakes to identify sites where surface area/basin area and evapotranspiration/precipitation are dominant controls on water level. Lakes that have strong alternative controls on lake level, such as the influences of groundwater, morphymetry, or those with significant outflow generally do not plot as the steady-state conditions would suggest. These parameters were not included in the model, because typically they are not known or easily estimated for most lakes.

The model suggests that a wide variety of lakes have some sensitivity to precipitation-evapotranspiration changes, as these lakes either plot within or near the threshold envelopes. Some of this sensitivity is based on the land cover of the lake basin, which is incorporated in the model with the $w$-value. We used lakes around the globe to interpret their current status, as well as potential factors that may cause deviation from model predictions in relation to their paleorecords. Interestingly, the conceptual model has successfully identified the lakes that are known to be permanent and ephemeral in relation to their paleorecords that give desiccation intervals and lake level trends. Lakes that plot within the threshold envelope are most likely sensitive to land use change.

The model can be used both to estimate past aridity index values or to estimate which lakes are likely to produce highresolution lake-level paleorecords. Thus the model may be useful in planning paleoclimatic studies based on lacustrine records, as well as identifying modern lakes where climate has 
a large influence on surface water hydrology and lake level. As our conceptual model identifies the impact of climate stress on lake hydrology, it may be used for both lake water management purposes, as well as examining the potential impacts of future climates on lake level trends.

Acknowledgments - We would like to thank the two anonymous reviewers for Journal of Hydrology for their useful comments that improved the manuscript. Robert Oglesby and John Gates provided comments on earlier versions of the manuscript.

Appendix A (Supplementary material) follows the References.

\section{References}

Aizen, V., Aizen, E., Kuzmichenok, V., 2007. Geo-informational simulation of possible changes in central Asian water resources. Global and Planetary Change 56, 341-358.

Allen, B., 2005. Ice age lakes in New Mexico. New Mexico Museum of Natural History and Science Bulletin 28, 107-114.

Allen, R., Pereira, L., Raes, D., Smith, M., 1998. Crop evapotranspiration: Guidelines for computing crop water requirements. Irrigation and Drainage Paper 56. Food and Agriculture Organization of the United Nations.

Alley, R., Marotzke, J., Nordhaus, W., Overpeck, J., Peteet, D., Pielke, R., Pierrehumvert, R., Rhines, P., Talley, T.S.L., Wallace, J., 2003. Abrupt climate change. Science 299, 2005-2010.

Atkinson, S., Woods, R., Sivapalan, M., 2002. Climate and landscape controls on water balance model complexity over changing timescales. Water Resources Research 38, 1314.

Ayenew, T., 2003. Evapotranspiration estimation using thematic mapper spectral satellite data in the Ethiopian Rift and adjacent highlands. Journal of Hydrology 279, 83-93.

Baker, P., Seltzer, G., Fritz, S., Dunbar, R., Grove, M., Tapia, P., Cross, S., Rowe, H., Broda, J., 2001. The history of South American tropical precipitation for the past 25,000 years. Science 291, 640-643.

Barrow, C., 2006. Land Degradation and Development. Edward Arnold. volume 3. chapter "World atlas of desertification" (United Nations environment program).

Bennett, D., Fritz, S.C., Holz, J., Holz, A., Zlotnik, V., 2007. Evaluating climatic and non-climatic influences on ion chemistry in natural and man-made lakes of Nebraska, USA. Hydrobiologia 591, 103-115.

Benson, L., Currey, D., Lao, Y., Hostetler, S., 1992. Lake-size variations in the Lahontan and Bonneville basins between 13,000 and 900014 c yr bp. Palaeogeography, Palaeoclimatology, Palaeoecology 95, 19-29.

Bergonzini, L., 2004. Zonal circulations over the Indian and Pacific Oceans and the level of Lakes Victoria and Tanganyika. International Journal of Climatology 24, 1613-1624.

Blodgett, T., Lenters, J., Isacks, D., 1997. Constraints on the origin of paleolake expansions in the central Andes. Earth Interactions 10, $1-28$.

Bowler, J., 1981. Australian salt lakes, a paleohydrological approach. Hydrobiologia 82, 431-444.

Bracht, B., Stone, J.R., Fritz, S.C., 2008. A diatom record of late Holocene climate variation in the northern range of Yellowstone National Park, USA. Quaternary International 188, 149-155.

Budyko, M., 1974. Climate and Life. Academic Press.

Choudhury, B., 1999. Evaluation of an empirical equation for annual evaporation using field observations and results from a biophysical model. Journal of Hydrology 216, 99-110.

Cohen, A., Stone, J.R., Beuning, K., Park, L., 2007. Ecological consequences of early Late Pleistocene megadroughts in tropical Africa. Proceedings of the National Academy of Sciences 104, 16422-16427.

Cook, E., Seager, R., Cane, M., Stahle, D., 2007. North American drought: reconstructions, causes, and consequences. Earth Science Reviews 81, 93-134.
Farmer, D., Sivapalan, M., Jothityangkoon, C., 2003. Climate, soil, and vegetation controls upon the variability of water balance in temperate and semiarid landscapes: downward approach to water balance analysis. Water Resources Research 39, 1035.

Fritz, S.C., 2008. Deciphering climatic history from lake sediments. Journal of Paleolimnology 39, 5-16.

Fritz, S.C., Baker, P., Seltzer, G., Ballantyne, A., Tapia, P., Cheng, H., Edwards, R., 2007. Quaternary glaciation and hydrologic variation in the South American tropics as reconstructed from the Lake Titicaca drilling project. Quaternary Research 68, 410-420.

Gao, H., Bohn, T., Podest, E., McDonald, K., Lettenmaier, D., 2011. On the causes of shrinking Lake Chad. Environmental Research Letters 6, 034021.

Gasse, F., Fontes, J., Plaziat, J., Carbonel, P., Kaczmarska, I., Deckker, P.D., Soulié- Marsche, I., Callot, Y., Dupeuble, P., 1987. Biological remains, geochemistry and stable isotopes for the reconstruction of environmental and hydrological changes in the Holocene lakes from North Sahara. Palaeogeography, Palaeoclimatology, Palaeoecology 60, 1-46.

George, D., Hurley, M., 2003. Using a continuous function for residence time to quantify the impact of climate change on the dynamics of thermally stratified lakes. Journal of Limnology 62, 21-26.

George, D., Talling, J., Rigg, E., 2000. Factors influencing the temporal coherence of five lakes in the English Lake District. Freshwater Biology 43, 449-461.

Hamblin, P., Verburg, P., Roebber, P., Bootsma, H., Hecky, R., 2004. The East African Great Lakes: Limnology. Palaeolimnology and Biodiversity. Kluwer Academic Publishers (chapter "Observations, Evaporation and Preliminary Modelling of Over-Lake Meteorology on Large African Lakes," pp. 121-151).

Hastenrath, S., 1985. Late Pleistocene climate and water budget of the South American Altiplano. Quaternary Research 24, 249-256.

Hostetler, S., Giorgi, F., 1995. Effects of a $2 \times \mathrm{CO}_{2}$ climate on two large lake systems: Pyramid Lake, Nevada, and Yellowstone Lake, Wyoming. Global and Planetary Change 10, 43-54.

Hostetler, S., Giorgi, F., Bates, G., Bartlein, P., 1994. Lake-atmosphere feedbacks associated with paleolakes Bonneville and Lahontan. Science 263, 665-668.

Hostetler, S., Bartlein, P., Clark, P., Small, E., 2000. Stimulated influences of Lake Agassiz on the climate of central North America 11,000 years ago. Nature 405, 334-337.

Jacobson, G., Jankowski, J., Abell, R., 1991. Groundwater and surface water interaction at Lake George, New South Wales. Journal of Australian Geology and Geophysics 12, 161-190.

Kessler, A., 1983. The paleohydrology of the late Pleistocene Lake Tauca on the Bolivian Altiplano and recent climatic fluctuations. SASQUA International Symposium, 115-122.

Kohfield, K., Harrison, S., 2000. How well can we simulate past climates? Evaluating the models using global palaeoenvironmental datasets. Quaternary Science Reviews 19, 321-346.

Koster, R., Suarez, M., 1999. A simple framework for examining the interannual variability of land surface moisture fluxes. Journal of Climate 12, 1911-1917.

Kutzbach, J., 1980. Estimates of past climate at paleolake Chad, North Africa, based on a hydrological and energy-balance model. Quaternary Research 14, 210-233.

Li, X., Xu, H., Sun, Y., Zhang, D., Yang, Z., 2007. Lake-level change and water balance analysis at Lake Qinghai, west China during recent decades. Water Resource Management 21, 1505-1516.

Mackay, A., 2007. The paleoclimatology of Lake Baikal: A diatom synthesis and prospectus. Earth Science Reviews 82, 181-215.

Micklin, P., 2007. The Aral Sea disaster. Annual Review of Earth and Planetary Sciences 35, 47-72.

Milly, P., Dunne, K., 1994. Sensitivity of the global water cycle to the water-holding capacity of land. Journal of Climate 7, 506-526.

Morrill, C., 2004. The influence of Asian summer monsoon variability on the water balance of a Tibetan lake. Journal of Paleolimnology 32, 273-286. 
Nicholson, S., Yin, X., 2002. The East African Great Lakes: Limnology, Palaeolimnology and Biodiversity. Kluwer Academic Publishers (chapter "Mesoscale patterns of rainfall, cloudiness and evaporation over the Great Lakes of East Africa," pp. 93-119).

Porporato, A., Daly, E., Rodriguez-Iturbe, I., 2004. Soil water balance and ecosystem response to climate change. American Naturalist $164,625-632$.

Qin, B., Huang, Q., 1998. Evaluation of the climatic change impacts on the inland lake-a case study of Lake Qinghai, China. Climatic Change 39, 695-714.

Redmond, K.T., 2007. Evaporation and the hydrologic budget of Crater Lake, Oregon. Hydrobiologia 574, 29-46.

Sass, G., Creed, I., Devito, K., 2008. Spatial heterogeneity in trophic status of shallow lakes on the Boreal Plain: influence of hydrologic setting. Water Resources Research 44, W08444.

Shapley, M., Ito, E., Donovan, J., 2002. Paleohydrology of lakes from isotopic and elemental chemistry. Geochimica et Cosmochimica Acta, 66.

Shinneman, A., Bennett, D., Fritz, S., Schmeider, J., Engstrom, D., Efing, A., Holz, J., 2010. Inferring lake depth using diatom assemblages in the shallow, seasonally variable lakes of the Nebraska Sand Hills, (USA): calibration and validation of a 69-lake training set. Journal of Paleolimnology 44, 443-464.

Song, Y., Semazzi, F., Xie, L., 2002. The East African Great Lakes: Limnology, Palaeolimnology and Biodiversity. Kluwer Academic Publishers (chapter "Development of a coupled regional climate simulation model for the Lake Victorian Basin," pp. 153-186).

Stevens, L., Stone, J.R., Campbell, J., Fritz, S.C., 2006. A 2200-yr record of hydrologic variability from Foy Lake, Montana, USA, inferred from diatom and geochemical data. Quaternary Research $65,264-274$.

Stine, S., 1994. Extreme and persistent drought in California and Patagonia during Mediaeval time. Nature 369, 549.

Stone, J.R., Fritz, S.C., 2004. Three-dimensional modeling of lacustrine diatom habitat areas: Improving paleolimnologic interpretation of planktic: benthic ratios. Limnology and Oceanography 49, 1540-1548.

Stone, J.R., Fritz, S.C., 2006. Multidecadal drought and Holocene climate instability in the Rocky Mountains. Geology 34, 409-412.

Street-Perrott, F., Harrison, S., 1985. Paleoclimate Analysis and Modeling. Wiley, New York (chapter "Lake levels and climate reconstruction," pp. 291-340).
Tate, E., Sutcliffe, J., Conway, D., Farquharson, F., 2004. Water balance of Lake Victoria: update to 2000 and climate change modelling to 2100. Hydrological Sciences Journal 49, 563-574.

Vassiljev, J., 1998. Simulating the Holocene lake-level record of Lake Bysjon, southern Sweden. Quaternary Research 49, 62-71.

Vassiljev, J., Harrison, S., Haxeltine, A., 1995. Recent lake-level and outflow variations at Lake Viljandi, Estonia: validation of a coupled lake-catchment modelling scheme for climate change studies. Journal of Hydrology 170, 63- 77.

Wang, T., Istanbulluoglu, E., Lenters, J., Scott, D., 2009. On the role of groundwater and soil texture in the regional water balance: an investigation on the Nebraska Sand Hills, USA. Water Resources Research 45, W10413.

Webster, K., Kratz, T., Bowser, C., Magnuson, J., 1996. The influence of landscape position on lake chemical responses to drought in northern Wisconsin. Limnology and Oceanography 41, 977-984.

Webster, K., Soranno, P., Baines, S., Kratz, T., 2000. Structuring features of lake districts: landscape controls on lake chemical responses to drought. Freshwater Biology 43, 499-515.

Whitlock, C., Dean, W., Fritz, S., Stevens, L., Stone, J., Power, M., Rosenbaum, J., Pierce, K., Bracht-Flyr, B., 2012. Holocene seasonal variability inferred from multiple proxy records from Crevice Lake, Yellowstone National Park, USA. Palaeogeography, Palaeoclimatology, Palaeoecology, 90-103.

Woodhouse, C., Russell, J., Cook, E., 2009. Two modes of North American drought from instrumental and paleoclimatic data. Journal of Climate 22, 4336-4347.

Zhang, L., Dawes, W., Walker, G., 2001. Response of mean annual evapotranspiration to vegetation changes at catchment scale. Water Resources Research 37, 701- 708.

Zhang, L., Hickel, K., Dawes, W., Chiew, F., Western, A., Briggs, P., 2004. A rational function approach for estimating mean annual evapotranspiration. Water Resources Research 40, W02502.

Zhang, L., Potter, N., Hickel, K., Zhang, Y., Shao, Q., 2008. Water balance modeling over variable time scales based on the Budyko framework-model development and testing. Journal of Hydrology 360, 117-131.

Zlotnik, V., Olaguera, J., Ong, J., 2009. An approach to assessment of flow regimes of groundwater-dominated lakes in arid environments. Journal of Hydrology 371, 22-30. 


\begin{tabular}{|c|c|c|c|c|c|c|}
\hline Lake & Lat & Long & $\begin{array}{l}\text { SA } \\
\text { (km2) }\end{array}$ & $\begin{array}{l}\text { CA } \\
\text { (km2) }\end{array}$ & $\begin{array}{l}\text { Precip( } \\
\text { mm) }\end{array}$ & $\begin{array}{l}\text { Evap } \\
(\mathrm{mm})\end{array}$ \\
\hline \multicolumn{7}{|l|}{ Africa } \\
\hline Abiyata & $7^{\circ} 30^{\prime} \mathrm{N}$ & $38^{\circ} 30^{\prime} E$ & 203 & 10740 & 552 & 1653 \\
\hline Malawi & $13^{\circ} 30^{\prime} \mathrm{S}$ & $34^{\circ} 00^{\prime} \mathrm{E}$ & 6400 & 6593 & 1350 & 1700 \\
\hline Massoko & $9^{\circ} 20^{\prime} \mathrm{S}$ & $33^{\circ} 45^{\prime} \mathrm{E}$ & 0.4 & 0.5 & 1300 & 500 \\
\hline Rukwa & $8^{\circ} 00^{\prime} S$ & $32^{\circ} 25^{\prime} E$ & 4000 & 78200 & 995 & 2000 \\
\hline Tanganyika & $10^{\circ} 00^{\prime} \mathrm{S}$ & $30^{\circ} 00^{\prime} \mathrm{E}$ & 32600 & 197400 & 1302 & 1251 \\
\hline Victoria & $1^{\circ} 25^{\prime} \mathrm{S}$ & $33^{\circ} 10^{\prime} E$ & 68800 & 184000 & 1780 & 1591 \\
\hline Langano & $7^{\circ} 37^{\prime} \mathrm{N}$ & $38^{\circ} 42^{\prime} \mathrm{E}$ & 230 & 2000 & 770 & 1921 \\
\hline $\begin{array}{l}\text { Modern } \\
\text { Chad* }\end{array}$ & $13^{\circ} 00^{\prime} \mathrm{N}$ & $14^{\circ} 00^{\prime} \mathrm{E}$ & 25000 & $\begin{array}{l}250000 \\
0\end{array}$ & 500 & 1297 \\
\hline $\begin{array}{l}\text { Paleolake } \\
\text { Chad }\end{array}$ & $13^{\circ} 0^{\prime} \mathrm{N}$ & $14^{\circ} 0^{\prime} E$ & 350000 & $\begin{array}{l}250000 \\
0\end{array}$ & 391 & 1297 \\
\hline Shala & $7^{\circ} 28^{\prime} \mathrm{N}$ & $38^{\circ} 31^{\prime} E$ & 370 & 2300 & 627 & 2110 \\
\hline Turkana & $3^{\circ} 03^{\prime} \mathrm{N}$ & $36^{\circ} 01^{\prime} \mathrm{E}$ & 6750 & 130860 & 250 & 2335 \\
\hline Ziway & $8^{\circ} 00^{\prime} \mathrm{N}$ & $38^{\circ} 49^{\prime} \mathrm{E}$ & 440 & 7380 & 734 & 2022 \\
\hline \multicolumn{7}{|l|}{ Asia } \\
\hline Ahung Co & $31^{\circ} 20^{\prime} \mathrm{N}$ & $92^{\circ} 5^{\prime} \mathrm{E}$ & 3.6 & 100 & 430 & 760 \\
\hline Aral & $45^{\circ} 00^{\prime} \mathrm{N}$ & $60^{\circ} 00^{\prime} \mathrm{E}$ & 66500 & $\begin{array}{l}100646 \\
0\end{array}$ & 200 & 1317 \\
\hline Baikal & $53^{\circ} 30^{\prime} \mathrm{N}$ & $108^{\circ} 10^{\prime} \mathrm{E}$ & 31500 & 557000 & 677 & 1321 \\
\hline Balkhash & $46^{\circ} 32^{\prime} \mathrm{N}$ & $74^{\circ} 52^{\prime} \mathrm{E}$ & 16434 & 521000 & 187 & 1141 \\
\hline $\mathrm{Ba} \mathrm{Be}$ & $22^{\circ} 02^{\prime} \mathrm{N}$ & $105^{\circ} 04^{\prime} \mathrm{E}$ & 4.5 & 454 & 1445 & 1354 \\
\hline Dal & $34^{\circ} 02^{\prime} \mathrm{N}$ & $75^{\circ} 04^{\prime} \mathrm{E}$ & 21 & 316 & 655 & 957 \\
\hline Dong-hu & $30^{\circ} 03^{\prime} \mathrm{N}$ & $114^{\circ} 02^{\prime} \mathrm{E}$ & 28 & 97 & 1450 & 1037 \\
\hline
\end{tabular}




\begin{tabular}{|c|c|c|c|c|c|c|}
\hline Lake & Lat & Long & $\begin{array}{l}\text { SA } \\
\text { (km2) }\end{array}$ & $\begin{array}{l}\text { CA } \\
\text { (km2) }\end{array}$ & $\begin{array}{l}\text { Precip( } \\
\text { mm) }\end{array}$ & $\begin{array}{l}\text { Evap } \\
(\mathrm{mm})\end{array}$ \\
\hline Issuk-kul & $42^{\circ} 30^{\prime} \mathrm{N}$ & $77^{\circ} 30^{\prime} \mathrm{E}$ & 6236 & 28127 & 258 & 984 \\
\hline Phewa & $28^{\circ} 01^{\prime} \mathrm{N}$ & $83^{\circ} 05^{\prime} \mathrm{E}$ & 5 & 110 & 1556 & 1151 \\
\hline Qinghai & $37^{\circ} 00^{\prime} \mathrm{N}$ & $100^{\circ} 00^{\prime} \mathrm{E}$ & 4304 & 29691 & 378 & 1459 \\
\hline \multicolumn{7}{|l|}{ Australia } \\
\hline Buchanan & $21^{\circ} 38^{\prime} S$ & $145^{\circ} 52^{\prime} \mathrm{E}$ & 115 & 3110 & 227 & 3000 \\
\hline Eyre & $28^{\circ} 30^{\prime} S$ & $137^{\circ} 20^{\prime} E$ & 9790 & $\begin{array}{l}131600 \\
0\end{array}$ & 500 & 1297 \\
\hline Frome & $30^{\circ} 37^{\prime} \mathrm{S}$ & $139^{\circ} 52^{\prime} \mathrm{E}$ & 2550 & 24500 & 232 & 1300 \\
\hline Gaililee & $22^{\circ} 19^{\prime} S$ & $145^{\circ} 50^{\prime} \mathrm{E}$ & 260 & 500 & 360 & 3000 \\
\hline Gairdner & $34^{\circ} 57^{\prime} \mathrm{S}$ & $118^{\circ} 08^{\prime} \mathrm{E}$ & 4520 & 11180 & 350 & 1900 \\
\hline George & $35^{\circ} 4^{\prime} \mathrm{S}$ & $149^{\circ} 25^{\prime} \mathrm{E}$ & 150 & 906 & 600 & 1050 \\
\hline Gregory & $25^{\circ} 38^{\prime} S$ & $119^{\circ} 58^{\prime} \mathrm{E}$ & 387 & 33160 & 300 & 1669 \\
\hline Keilambete & $38^{\circ} 12^{\prime} S$ & $142^{\circ} 52^{\prime} \mathrm{E}$ & 2.7 & 4.1 & 400 & 900 \\
\hline Torrens & $31^{\circ} 02^{\prime} S$ & $137^{\circ} 51^{\prime} \mathrm{E}$ & 5640 & 27000 & 186 & 1500 \\
\hline Tyrrell & $35^{\circ} 21^{\prime} \mathrm{S}$ & $142^{\circ} 50^{\prime} \mathrm{E}$ & 155 & 647 & 323 & 890 \\
\hline Woods & $17^{\circ} 43^{\prime} S$ & $139^{\circ} 30^{\prime} \mathrm{E}$ & 423 & 25300 & 302 & 1600 \\
\hline \multicolumn{7}{|l|}{ Europe } \\
\hline Amara & $45^{\circ} 13^{\prime} \mathrm{N}$ & $27^{\circ} 17^{\prime} \mathrm{E}$ & 1.5 & 47 & 429 & 836 \\
\hline Balta Alba & $45^{\circ} 02^{\prime} \mathrm{N}$ & $27^{\circ} 02^{\prime} \mathrm{E}$ & 11.0 & 91.6 & 429 & 836 \\
\hline Banyoles & $42^{\circ} 08^{\prime} \mathrm{N}$ & $2^{\circ} 45^{\prime} E$ & 1.1 & 11.4 & 804 & 937 \\
\hline $\begin{array}{l}\text { Bassenthwait } \\
\text { he }\end{array}$ & $54^{\circ} 39^{\prime} \mathrm{N}$ & $3^{\circ} 13^{\prime} \mathrm{W}$ & 5.3 & 237 & 1300 & 500 \\
\hline Blelham Tarn & $54^{\circ} 24^{\prime} \mathrm{N}$ & $2^{\circ} 59^{\prime} \mathrm{W}$ & 0.1 & 4 & 1918 & 500 \\
\hline
\end{tabular}




\begin{tabular}{|l|l|l|l|l|l|l|}
\hline \multicolumn{1}{|c|}{ Lake } & \multicolumn{1}{|c|}{ Lat } & \multicolumn{1}{|c|}{ Long } & $\begin{array}{l}\text { SA } \\
(\mathbf{k m 2})\end{array}$ & $\begin{array}{l}\text { CA } \\
(\mathbf{k m} 2)\end{array}$ & $\begin{array}{l}\text { Precip( } \\
\mathbf{m m})\end{array}$ & $\begin{array}{l}\text { Evap } \\
(\mathbf{m m})\end{array}$ \\
\hline Chervonoje & $52^{\circ} 2^{\prime} \mathrm{N}$ & $27^{\circ} 5^{\prime} \mathrm{E}$ & 40.0 & 353 & 656 & 663 \\
\hline $\begin{array}{l}\text { Esthwaite } \\
\text { Water }\end{array}$ & $54^{\circ} 21^{\prime} \mathrm{N}$ & $2^{\circ} 58^{\prime} \mathrm{W}$ & 1.0 & 17 & 1912 & 500 \\
\hline Grasmere & $49^{\circ} 04^{\prime} \mathrm{N}$ & $1^{\circ} 15^{\prime} \mathrm{W}$ & 0.6 & 28 & 2553 & 500 \\
\hline Karujarv & $58^{\circ} 23^{\prime} \mathrm{N}$ & $22^{\circ} 13^{\prime} \mathrm{E}$ & 3.3 & 16.1 & 238 & 235 \\
\hline Kirjaku* & $59^{\circ} 15^{\prime} \mathrm{N}$ & $27^{\circ} 35^{\prime} \mathrm{E}$ & 0.2 & 30.8 & 238 & 235 \\
\hline Lake Bysjon & $55^{\circ} 40^{\prime} \mathrm{N}$ & $13^{\circ} 32^{\prime} \mathrm{E}$ & 0.2 & 0.9 & 587 & 619 \\
\hline Loch Shiel & $56^{\circ} 05^{\prime} \mathrm{N}$ & $5^{\circ} 04^{\prime} \mathrm{W}$ & 20.0 & 234 & 1300 & 500 \\
\hline Vijandi & $58^{\circ} 20^{\prime} \mathrm{N}$ & $25^{\circ} 35^{\prime} \mathrm{E}$ & 1.6 & 66.8 & 238 & 235 \\
\hline $\begin{array}{l}\text { Windermere } \\
\text { (NB) }\end{array}$ & $54^{\circ} 21^{\prime} \mathrm{N}$ & $2^{\circ} 56^{\prime} \mathrm{W}$ & 8.1 & 198 & 1300 & 500 \\
\hline $\begin{array}{l}\text { Windermere } \\
\text { (SB) }\end{array}$ & $54^{\circ} 21^{\prime} \mathrm{N}$ & $2^{\circ} 56^{\prime} \mathrm{W}$ & 6.7 & 32 & 1300 & 500 \\
\hline $\begin{array}{l}\text { North } \\
\text { America }\end{array}$ & $42^{\circ} 56^{\prime} \mathrm{N}$ & $122^{\circ} 06^{\prime} \mathrm{W}$ & 53.2 & 67.8 & 1692 & 1270 \\
\hline Crater & $47^{\circ} 52^{\prime} \mathrm{N}$ & $113^{\circ} 39^{\prime} \mathrm{W}$ & 0.1 & 0.2 & 356 & 1100 \\
\hline Crevice & $48^{\circ} 5^{\prime} \mathrm{N}$ & $114^{\circ} 15^{\prime} \mathrm{W}$ & 0.9 & 13.6 & 406 & 1100 \\
\hline Foy & $40^{\circ} 42^{\prime} \mathrm{N}$ & $112^{\circ} 23^{\prime} \mathrm{W}$ & 4400 & 89000 & 419 & 1349 \\
\hline Great Salt & $38^{\circ} 0^{\prime} \mathrm{N}$ & $119^{\circ} 0^{\prime} \mathrm{W}$ & 227 & 1800 & 355 & 1981 \\
\hline Mono & $44^{\circ} 36^{\prime} \mathrm{N}$ & $113^{\circ} 02^{\prime} \mathrm{W}$ & 0.1 & 2 & 406 & 1100 \\
\hline Morrison & $113^{\circ} 27^{\prime} \mathrm{W}$ & 0.2 & 2.8 & 381 & 1100 \\
\hline Pyramid & $40^{\circ} \mathrm{N}$ & $119^{\circ} 30^{\prime} \mathrm{W}$ & 430 & 2620 & 500 & 1300 \\
\hline Reservoir & $45^{\circ} \mathrm{N}$ & & & & \\
\hline
\end{tabular}




\begin{tabular}{|c|c|c|c|c|c|c|}
\hline Lake & Lat & Long & $\begin{array}{l}\text { SA } \\
\text { (km2) }\end{array}$ & $\begin{array}{l}\text { CA } \\
\text { (km2) }\end{array}$ & $\begin{array}{l}\text { Precip( } \\
\text { mm) }\end{array}$ & $\begin{array}{l}\text { Evap } \\
(\mathrm{mm})\end{array}$ \\
\hline Sammamish & $47^{\circ} 33^{\prime} \mathrm{N}$ & $122^{\circ} 03^{\prime} \mathrm{W}$ & 19.8 & 255 & 800 & 818 \\
\hline Washington & $47^{\circ} 37^{\prime} \mathrm{N}$ & $122^{\circ} 15^{\prime} \mathrm{W}$ & 87.6 & 1274 & 799 & 1234 \\
\hline Yellowstone & $44^{\circ} 30^{\prime} \mathrm{N}$ & $115^{\circ} 30^{\prime} \mathrm{W}$ & 360 & 7100 & 516 & 973 \\
\hline \multicolumn{7}{|l|}{ Southwest } \\
\hline Animas & $32^{\circ} 28^{\prime} \mathrm{N}$ & $108^{\circ} 54^{\prime} \mathrm{W}$ & 374 & 5670 & 250 & 1840 \\
\hline Cloverdale & $31^{\circ} 00^{\prime} \mathrm{N}$ & $108^{\circ} 00^{\prime} \mathrm{W}$ & 102 & 460 & 410 & 1780 \\
\hline Encino & $34^{\circ} 00^{\prime} \mathrm{N}$ & $105^{\circ} 00^{\prime} \mathrm{W}$ & 96 & 620 & 350 & 1370 \\
\hline Estancia & $34^{\circ} 45^{\prime} \mathrm{N}$ & $106^{\circ} 03^{\prime} \mathrm{W}$ & 1125 & 5050 & 310 & 1270 \\
\hline Goodsight & $32^{\circ} 19^{\prime} \mathrm{N}$ & $108^{\circ} 45^{\prime} \mathrm{W}$ & 65 & 590 & 250 & 1830 \\
\hline Otero & $32^{\circ} 32^{\prime} \mathrm{N}$ & $105^{\circ} 46^{\prime} \mathrm{W}$ & 745 & 126000 & 250 & 1660 \\
\hline Pinos Well & $34^{\circ} 27^{\prime} \mathrm{N}$ & $105^{\circ} 38^{\prime} \mathrm{W}$ & 82 & 560 & 360 & 1320 \\
\hline Playas & $31^{\circ} 50^{\prime} \mathrm{N}$ & $108^{\circ} 34^{\prime} \mathrm{W}$ & 49 & 1120 & 270 & 1900 \\
\hline Sacramento & $32^{\circ} 45^{\prime} \mathrm{N}$ & $105^{\circ} 46^{\prime} \mathrm{W}$ & 86 & 780 & 250 & 1650 \\
\hline San Agustin & $33^{\circ} 52^{\prime} \mathrm{N}$ & $108^{\circ} 15^{\prime} \mathrm{W}$ & 786 & 3880 & 290 & 1150 \\
\hline Trinity & $33^{\circ} 40^{\prime} \mathrm{N}$ & $106^{\circ} 28^{\prime} \mathrm{W}$ & 207 & 4240 & 250 & 1590 \\
\hline \multicolumn{7}{|l|}{ LTER } \\
\hline Allequash & $46^{\circ} 02^{\prime} \mathrm{N}$ & $89^{\circ} 37^{\prime} \mathrm{W}$ & 1.7 & 6.3 & 800 & 1000 \\
\hline Arrowhead & $45^{\circ} 54^{\prime} \mathrm{N}$ & $89^{\circ} 41^{\prime} \mathrm{W}$ & 0.4 & 2.4 & 800 & 1000 \\
\hline Beaver & $46^{\circ} 12^{\prime} \mathrm{N}$ & $89^{\circ} 35^{\prime} \mathrm{W}$ & 0.3 & 4.6 & 800 & 1000 \\
\hline
\end{tabular}




\begin{tabular}{|l|l|l|l|l|l|l|}
\hline \multicolumn{1}{|c|}{ Lake } & Lat & \multicolumn{1}{|c|}{ Long } & $\begin{array}{l}\text { SA } \\
(\mathbf{k m 2})\end{array}$ & $\begin{array}{l}\text { CA } \\
(\mathbf{k m} 2)\end{array}$ & $\begin{array}{l}\text { Precip( } \\
\mathbf{m m})\end{array}$ & $\begin{array}{l}\text { Evap } \\
(\mathbf{m m})\end{array}$ \\
\hline Big & $46^{\circ} 09^{\prime} \mathrm{N}$ & $89^{\circ} 46^{\prime} \mathrm{W}$ & 3.3 & 10.4 & 800 & 1000 \\
\hline Big Crooked & $46^{\circ} 02^{\prime} \mathrm{N}$ & $89^{\circ} 51^{\prime} \mathrm{W}$ & 2.7 & 6.0 & 800 & 1000 \\
\hline Big Gibson & $46^{\circ} 08^{\prime} \mathrm{N}$ & $89^{\circ} 33^{\prime} \mathrm{W}$ & 0.5 & 1.1 & 800 & 1000 \\
\hline $\begin{array}{l}\text { Big } \\
\text { Muskellunge }\end{array}$ & $46^{\circ} 01^{\prime} \mathrm{N}$ & $89^{\circ} 36^{\prime} \mathrm{W}$ & 3.6 & 7.8 & 800 & 1000 \\
\hline Boulder & $45^{\circ} 08^{\prime} \mathrm{N}$ & $88^{\circ} 38^{\prime} \mathrm{W}$ & 2.2 & 14.3 & 800 & 1000 \\
\hline Brandy & $45^{\circ} 54^{\prime} \mathrm{N}$ & $89^{\circ} 42^{\prime} \mathrm{W}$ & 0.4 & 1.0 & 800 & 1000 \\
\hline Crampton & $46^{\circ} 12^{\prime} \mathrm{N}$ & $89^{\circ} 28^{\prime} \mathrm{W}$ & 0.3 & 0.7 & 800 & 1000 \\
\hline Crystal & $46^{\circ} 00^{\prime} \mathrm{N}$ & $89^{\circ} 36^{\prime} \mathrm{W}$ & 0.4 & 1.8 & 800 & 1000 \\
\hline Diamond & $46^{\circ} 02^{\prime} \mathrm{N}$ & $89^{\circ} 42^{\prime} \mathrm{W}$ & 0.5 & 1.2 & 800 & 1000 \\
\hline Flora & $46^{\circ} 10^{\prime} \mathrm{N}$ & $89^{\circ} 39^{\prime} \mathrm{W}$ & 0.4 & 2.2 & 800 & 1000 \\
\hline Heart & $46^{\circ} 05^{\prime} \mathrm{N}$ & $89^{\circ} 16^{\prime} \mathrm{W}$ & 0.1 & 0.5 & 800 & 1000 \\
\hline Ike Walton & $46^{\circ} 02^{\prime} \mathrm{N}$ & $89^{\circ} 48^{\prime} \mathrm{W}$ & 5.7 & 13.2 & 800 & 1000 \\
\hline Island & $46^{\circ} 06^{\prime} \mathrm{N}$ & $89^{\circ} 47^{\prime} \mathrm{W}$ & 3.6 & 12.5 & 800 & 1000 \\
\hline Johnson & $46^{\circ} 08^{\prime} \mathrm{N}$ & $89^{\circ} 31^{\prime} \mathrm{W}$ & 0.3 & 1.7 & 800 & 1000 \\
\hline Katherine & $45^{\circ} 48^{\prime} \mathrm{N}$ & $89^{\circ} 42^{\prime} \mathrm{W}$ & 2.1 & 6.6 & 800 & 1000 \\
\hline Kathleen & $45^{\circ} 14^{\prime} \mathrm{N}$ & $88^{\circ} 38^{\prime} \mathrm{W}$ & 0.1 & 0.3 & 800 & 1000 \\
\hline Katinka & $46^{\circ} 12^{\prime} \mathrm{N}$ & $89^{\circ} 47^{\prime} \mathrm{W}$ & 0.7 & 1.6 & 800 & 1000 \\
\hline Lehto & $46^{\circ} 01^{\prime} \mathrm{N}$ & $9^{\circ} 02^{\prime} \mathrm{W}$ & 0.3 & 7.4 & 800 & 1000 \\
\hline $\begin{array}{l}\text { Little } \\
\text { Crooked }\end{array}$ & $46^{\circ} 08^{\prime} \mathrm{N}$ & $89^{\circ} 41^{\prime} \mathrm{W}$ & 0.6 & 3.2 & 800 & 1000 \\
\hline Little Spider & $45^{\circ} 58^{\prime} \mathrm{N}$ & $89^{\circ} 42^{\prime} \mathrm{W}$ & 0.9 & 2.1 & 800 & 1000 \\
\hline Sittle & $46^{\circ} 01^{\prime} \mathrm{N}$ & $89^{\circ} 51^{\prime} \mathrm{W}$ & 0.2 & 0.8 & 800 & 1000 \\
\hline
\end{tabular}




\begin{tabular}{|l|l|l|l|l|l|l|}
\hline \multicolumn{1}{|c|}{ Lake } & Lat & \multicolumn{1}{|c|}{ Long } & $\begin{array}{l}\text { SA } \\
(\mathbf{k m 2})\end{array}$ & $\begin{array}{l}\text { CA } \\
(\mathbf{k m} 2)\end{array}$ & $\begin{array}{l}\text { Precip( } \\
\mathbf{m m})\end{array}$ & $\begin{array}{l}\text { Evap } \\
(\mathbf{m m})\end{array}$ \\
\hline Little Trout & $46^{\circ} 04^{\prime} \mathrm{N}$ & $89^{\circ} 51^{\prime} \mathrm{W}$ & 4.1 & 7.6 & 800 & 1000 \\
\hline $\begin{array}{l}\text { Lower } \\
\text { Kaubeshine }\end{array}$ & $45^{\circ} 48^{\prime} \mathrm{N}$ & $89^{\circ} 44^{\prime} \mathrm{W}$ & 0.8 & 2.8 & 800 & 1000 \\
\hline Lynx & $45^{\circ} 56^{\prime} \mathrm{N}$ & $89^{\circ} 13^{\prime} \mathrm{W}$ & 1.2 & 2.8 & 800 & 1000 \\
\hline McCullough & $46^{\circ} 11^{\prime} \mathrm{N}$ & $89^{\circ} 34^{\prime} \mathrm{W}$ & 0.9 & 3.3 & 800 & 1000 \\
\hline Mid & $45^{\circ} 51^{\prime} \mathrm{N}$ & $89^{\circ} 39^{\prime} \mathrm{W}$ & 1.0 & 2.7 & 800 & 1000 \\
\hline Minocqua & $45^{\circ} 52^{\prime} \mathrm{N}$ & $89^{\circ} 41^{\prime} \mathrm{W}$ & 8.1 & 11.7 & 800 & 1000 \\
\hline Muskesin & $46^{\circ} 01^{\prime} \mathrm{N}$ & $89^{\circ} 54^{\prime} \mathrm{W}$ & 0.5 & 1.3 & 800 & 1000 \\
\hline Nixon & $46^{\circ} 05^{\prime} \mathrm{N}$ & $89^{\circ} 33^{\prime} \mathrm{W}$ & 0.5 & 9.6 & 800 & 1000 \\
\hline Partridge & $46^{\circ} 04^{\prime} \mathrm{N}$ & $89^{\circ} 30^{\prime} \mathrm{W}$ & 1.0 & 3.3 & 800 & 1000 \\
\hline Randall & $46^{\circ} 01^{\prime} \mathrm{N}$ & $90^{\circ} 01^{\prime} \mathrm{W}$ & 0.5 & 4.3 & 800 & 1000 \\
\hline Round & $46^{\circ} 10^{\prime} \mathrm{N}$ & $89^{\circ} 42^{\prime} \mathrm{W}$ & 0.7 & 5.7 & 800 & 1000 \\
\hline Sanford & $46^{\circ} 10^{\prime} \mathrm{N}$ & $89^{\circ} 41^{\prime} \mathrm{W}$ & 0.4 & 1.5 & 800 & 1000 \\
\hline Sparkling & $46^{\circ} 00^{\prime} \mathrm{N}$ & $89^{\circ} 41^{\prime} \mathrm{W}$ & 0.6 & 1.1 & 800 & 1000 \\
\hline Statenaker & $45^{\circ} 58^{\prime} \mathrm{N}$ & $89^{\circ} 46^{\prime} \mathrm{W}$ & 0.8 & 1.9 & 800 & 1000 \\
\hline Stearns & $45^{\circ} 59^{\prime} \mathrm{N}$ & $89^{\circ} 48^{\prime} \mathrm{W}$ & 1.0 & 2.0 & 800 & 1000 \\
\hline Tomahawk & $45^{\circ} 49^{\prime} \mathrm{N}$ & $89^{\circ} 39^{\prime} \mathrm{W}$ & 15.0 & 25.4 & 800 & 1000 \\
\hline Trout & $46^{\circ} 02^{\prime} \mathrm{N}$ & $89^{\circ} 40^{\prime} \mathrm{W}$ & 15.7 & 23.6 & 800 & 1000 \\
\hline $\begin{array}{l}\text { Upper } \\
\text { Kaubeshine }\end{array}$ & $45^{\circ} 47^{\prime} \mathrm{N}$ & $89^{\circ} 44^{\prime} \mathrm{W}$ & 0.7 & 2.1 & 800 & 1000 \\
\hline White Birch & $45^{\circ} 39^{\prime} \mathrm{N}$ & $91^{\circ} 09^{\prime} \mathrm{W}$ & 0.5 & 1.0 & 800 & 1000 \\
\hline White Sand & $46^{\circ} 05^{\prime} \mathrm{N}$ & $89^{\circ} 35^{\prime} \mathrm{W}$ & 3.0 & 5.5 & 800 & 1000 \\
\hline Wild Rice* & $46^{\circ} 03^{\prime} \mathrm{N}$ & $89^{\circ} 47^{\prime} \mathrm{W}$ & 1.5 & 153.1 & 800 & 1000 \\
\hline Wildcat & $89^{\circ} 37^{\prime} \mathrm{W}$ & 1.4 & 4.1 & 800 & 1000 \\
\hline
\end{tabular}




\begin{tabular}{|l|l|l|l|l|l|l|}
\hline Lake & Lat & Long & $\begin{array}{l}\text { SA } \\
(\mathbf{k m 2})\end{array}$ & $\begin{array}{l}\text { CA } \\
(\mathbf{k m} 2)\end{array}$ & $\begin{array}{l}\text { Precip( } \\
\mathbf{m m})\end{array}$ & $\begin{array}{l}\text { Evap } \\
(\mathbf{m m})\end{array}$ \\
\hline ELA & & & & & & \\
\hline 93 & $49^{\circ} 40^{\prime} \mathrm{N}$ & $93^{\circ} 43^{\prime} \mathrm{W}$ & 5.5 & 60 & 684 & 525 \\
\hline 106 & $49^{\circ} 40^{\prime} \mathrm{N}$ & $93^{\circ} 43^{\prime} \mathrm{W}$ & 3.7 & 121 & 684 & 525 \\
\hline 109 & $49^{\circ} 40^{\prime} \mathrm{N}$ & $93^{\circ} 43^{\prime} \mathrm{W}$ & 14.9 & 42 & 684 & 525 \\
\hline 110 & $49^{\circ} 40^{\prime} \mathrm{N}$ & $93^{\circ} 43^{\prime} \mathrm{W}$ & 5.3 & 34 & 684 & 525 \\
\hline 111 & $49^{\circ} 40^{\prime} \mathrm{N}$ & $93^{\circ} 43^{\prime} \mathrm{W}$ & 9.6 & 339 & 684 & 525 \\
\hline 114 & $49^{\circ} 40^{\prime} \mathrm{N}$ & $93^{\circ} 43^{\prime} \mathrm{W}$ & 12.1 & 58 & 684 & 525 \\
\hline 115 & $49^{\circ} 40^{\prime} \mathrm{N}$ & $93^{\circ} 43^{\prime} \mathrm{W}$ & 6.5 & 119 & 684 & 525 \\
\hline 149 & $49^{\circ} 40^{\prime} \mathrm{N}$ & $93^{\circ} 43^{\prime} \mathrm{W}$ & 26.9 & 94 & 684 & 525 \\
\hline $164 *$ & $49^{\circ} 40^{\prime} \mathrm{N}$ & $93^{\circ} 43^{\prime} \mathrm{W}$ & 20.3 & 4984 & 684 & 525 \\
\hline $165 *$ & $49^{\circ} 40^{\prime} \mathrm{N}$ & $93^{\circ} 43^{\prime} \mathrm{W}$ & 18.4 & 4802 & 684 & 525 \\
\hline 191 & $49^{\circ} 40^{\prime} \mathrm{N}$ & $93^{\circ} 43^{\prime} \mathrm{W}$ & 19.4 & 338 & 684 & 525 \\
\hline 220 & $49^{\circ} 40^{\prime} \mathrm{N}$ & $93^{\circ} 43^{\prime} \mathrm{W}$ & 1.6 & 20 & 684 & 525 \\
\hline 221 & $49^{\circ} 40^{\prime} \mathrm{N}$ & $93^{\circ} 43^{\prime} \mathrm{W}$ & 9 & 82 & 684 & 525 \\
\hline 222 & $49^{\circ} 40^{\prime} \mathrm{N}$ & $93^{\circ} 43^{\prime} \mathrm{W}$ & 16.4 & 204 & 684 & 525 \\
\hline 223 & $49^{\circ} 40^{\prime} \mathrm{N}$ & $93^{\circ} 43^{\prime} \mathrm{W}$ & 27.3 & 260 & 684 & 525 \\
\hline 224 & $49^{\circ} 40^{\prime} \mathrm{N}$ & $93^{\circ} 43^{\prime} \mathrm{W}$ & 25.9 & 98 & 684 & 525 \\
\hline 225 & $49^{\circ} 40^{\prime} \mathrm{N}$ & $93^{\circ} 43^{\prime} \mathrm{W}$ & 4 & 31 & 684 & 525 \\
\hline 226 & $49^{\circ} 40^{\prime} \mathrm{N}$ & $93^{\circ} 43^{\prime} \mathrm{W}$ & 16.1 & 97 & 684 & 525 \\
\hline 227 & $49^{\circ} 40^{\prime} \mathrm{N}$ & $93^{\circ} 43^{\prime} \mathrm{W}$ & 5 & 34 & 684 & 525 \\
\hline 239 & $49^{\circ} 40^{\prime} \mathrm{N}$ & $93^{\circ} 43^{\prime} \mathrm{W}$ & 56.1 & 391 & 684 & 525 \\
\hline 240 & $49^{\circ} 40^{\prime} \mathrm{N}$ & $93^{\circ} 43^{\prime} \mathrm{W}$ & 44.1 & 720 & 684 & 525 \\
\hline 260 & & $93^{\circ} \mathrm{W}$ & 34 & 166 & 684 & 525 \\
\hline
\end{tabular}




\begin{tabular}{|l|l|l|l|l|l|l|}
\hline Lake & Lat & Long & $\begin{array}{l}\text { SA } \\
(\mathbf{k m 2})\end{array}$ & $\begin{array}{l}\text { CA } \\
(\mathbf{k m} 2)\end{array}$ & $\begin{array}{l}\text { Precip( } \\
\mathbf{m m})\end{array}$ & $\begin{array}{l}\text { Evap } \\
(\mathbf{m m})\end{array}$ \\
\hline 261 & $49^{\circ} 40^{\prime} \mathrm{N}$ & $93^{\circ} 43^{\prime} \mathrm{W}$ & 5.6 & 42 & 684 & 525 \\
\hline 262 & $49^{\circ} 40^{\prime} \mathrm{N}$ & $93^{\circ} 43^{\prime} \mathrm{W}$ & 84.2 & 1230 & 684 & 525 \\
\hline 265 & $49^{\circ} 40^{\prime} \mathrm{N}$ & $93^{\circ} 43^{\prime} \mathrm{W}$ & 13.1 & 71 & 684 & 525 \\
\hline 302 & $49^{\circ} 40^{\prime} \mathrm{N}$ & $93^{\circ} 43^{\prime} \mathrm{W}$ & 23.7 & 103 & 684 & 525 \\
\hline 303 & $49^{\circ} 40^{\prime} \mathrm{N}$ & $93^{\circ} 43^{\prime} \mathrm{W}$ & 9.5 & 54 & 684 & 525 \\
\hline 304 & $49^{\circ} 40^{\prime} \mathrm{N}$ & $93^{\circ} 43^{\prime} \mathrm{W}$ & 3.4 & 26 & 684 & 525 \\
\hline 305 & $49^{\circ} 40^{\prime} \mathrm{N}$ & $93^{\circ} 43^{\prime} \mathrm{W}$ & 52 & 237 & 684 & 525 \\
\hline $309 *$ & $49^{\circ} 40^{\prime} \mathrm{N}$ & $93^{\circ} 43^{\prime} \mathrm{W}$ & 2.6 & 560 & 684 & 525 \\
\hline 310 & $49^{\circ} 40^{\prime} \mathrm{N}$ & $93^{\circ} 43^{\prime} \mathrm{W}$ & 49.7 & 539 & 684 & 525 \\
\hline 373 & $49^{\circ} 40^{\prime} \mathrm{N}$ & $93^{\circ} 43^{\prime} \mathrm{W}$ & 27.6 & 83 & 684 & 525 \\
\hline 375 & $49^{\circ} 40^{\prime} \mathrm{N}$ & $93^{\circ} 43^{\prime} \mathrm{W}$ & 18.9 & 231 & 684 & 525 \\
\hline 377 & $49^{\circ} 40^{\prime} \mathrm{N}$ & $93^{\circ} 43^{\prime} \mathrm{W}$ & 26.7 & 2030 & 684 & 525 \\
\hline 378 & $49^{\circ} 40^{\prime} \mathrm{N}$ & $93^{\circ} 43^{\prime} \mathrm{W}$ & 24.3 & 136 & 684 & 525 \\
\hline 382 & $49^{\circ} 40^{\prime} \mathrm{N}$ & $93^{\circ} 43^{\prime} \mathrm{W}$ & 36.9 & 205 & 684 & 525 \\
\hline 383 & $49^{\circ} 40^{\prime} \mathrm{N}$ & $93^{\circ} 43^{\prime} \mathrm{W}$ & 5.6 & 40 & 684 & 525 \\
\hline 385 & $49^{\circ} 40^{\prime} \mathrm{N}$ & $93^{\circ} 43^{\prime} \mathrm{W}$ & 24.9 & 102 & 684 & 525 \\
\hline 421 & $49^{\circ} 40^{\prime} \mathrm{N}$ & $93^{\circ} 43^{\prime} \mathrm{W}$ & 17 & 51 & 684 & 525 \\
\hline 428 & $49^{\circ} 40^{\prime} \mathrm{N}$ & $93^{\circ} 43^{\prime} \mathrm{W}$ & 6 & 44 & 684 & 525 \\
\hline 442 & $49^{\circ} 40^{\prime} \mathrm{N}$ & $93^{\circ} 43^{\prime} \mathrm{W}$ & 15.2 & 184 & 684 & 525 \\
\hline 470 & $49^{\circ} 40^{\prime} \mathrm{N}$ & $93^{\circ} 43^{\prime} \mathrm{W}$ & 5.7 & 168 & 684 & 525 \\
\hline 622 & $49^{\circ} 40^{\prime} \mathrm{N}$ & $93^{\circ} 43^{\prime} \mathrm{W}$ & 38.6 & 419 & 684 & 525 \\
\hline 623 & $49^{\circ} 40^{\prime} \mathrm{N}$ & $93^{\circ} 43^{\prime} \mathrm{W}$ & 36 & 651 & 684 & 525 \\
\hline 624 & $93^{\circ} 43^{\prime} \mathrm{W}$ & 2 & 27.9 & 388 & 684 & 525 \\
\hline $626 *$ & 453 & 684 & 525 \\
\hline
\end{tabular}




\begin{tabular}{|l|l|l|l|l|l|l|}
\hline \multicolumn{1}{|c|}{ Lake } & Lat & \multicolumn{1}{|c|}{ Long } & $\begin{array}{l}\text { SA } \\
\mathbf{( k m 2 )}\end{array}$ & $\begin{array}{l}\text { CA } \\
(\mathbf{k m} 2)\end{array}$ & $\begin{array}{l}\text { Precip( } \\
\mathbf{m m})\end{array}$ & $\begin{array}{l}\text { Evap } \\
\mathbf{( m m})\end{array}$ \\
\hline 629 & $49^{\circ} 40^{\prime} \mathrm{N}$ & $93^{\circ} 43^{\prime} \mathrm{W}$ & 35.5 & 348 & 684 & 525 \\
\hline 658 & $49^{\circ} 40^{\prime} \mathrm{N}$ & $93^{\circ} 43^{\prime} \mathrm{W}$ & 63.1 & 125 & 684 & 525 \\
\hline $\begin{array}{l}\text { South } \\
\text { America }\end{array}$ & & & & & & \\
\hline Amatitlan & $14^{\circ} 08^{\prime} \mathrm{N}$ & $90^{\circ} 06^{\prime} \mathrm{W}$ & 15.2 & 368 & 1124 & 1150 \\
\hline Chapala & $20^{\circ} 01^{\prime} \mathrm{N}$ & $13^{\circ} 06^{\prime} \mathrm{W}$ & 1112 & 52500 & 893 & 1601 \\
\hline $\begin{array}{l}\text { Laguna de } \\
\text { Rocha }\end{array}$ & $3^{\circ} 04^{\prime} \mathrm{S}$ & $54^{\circ} 01^{\prime} \mathrm{W}$ & 72 & 1312 & 1073 & 1058 \\
\hline $\begin{array}{l}\text { Paleo Tauca } \\
1\end{array}$ & $13^{\circ} 28^{\prime} \mathrm{S}$ & $72^{\circ} 02^{\prime} \mathrm{W}$ & 22700 & 73500 & 600 & 1494 \\
\hline Poopo & $18^{\circ} 33^{\prime} \mathrm{S}$ & $67^{\circ} 05^{\prime} \mathrm{W}$ & 1000 & 27700 & 250 & 1494 \\
\hline $\begin{array}{l}\text { Paleo Tauca } \\
2\end{array}$ & $13^{\circ} 28^{\prime} \mathrm{S}$ & $72^{\circ} 02^{\prime} \mathrm{W}$ & 20300 & 73500 & 310 & 1494 \\
\hline Titicaca & $15^{\circ} 50^{\prime} \mathrm{S}$ & $69^{\circ} 20^{\prime} \mathrm{W}$ & 285006 & 580000 & 737 & 1270 \\
\hline
\end{tabular}

